\author{
鼻過敏症とムスカリニック受容体 \\ 一臨床症状との相関性一 \\ 安 藤 英 樹
}

\title{
The Relationship between Muscarinic Cholinergic Receptors and Hyperesthetic Rhinitis
}

\author{
Hideki Ando \\ (Akita University School of Medicine)
}

It is generally accepted that abnormal autonomic responsiveness may contribute to the pathogenesis of hyperesthetic rhinitis. Histologically, cholinergic fibers in the nasal mucosa are located close to blood vessels, but are particularly numerous around the glands. Adrenergic fibers are found mainly around the vasculatures. Physiological and pharmacological studies have demonstrated that parasympathetic hypersensitivity causes hypersecretion, and that sympathetic hypersensitivity causes vasodilatation.

Using radioligand binding techniques, it has been found that there is an increased number of muscarinic cholinergic receptors and a decreased number of $\alpha_{1}$ - and $\beta$-adrenergic receptors in patients with nasal allergy, while the binding affinities remain unchanged.

In this report, using radioligand binding techniques, I investigated the relationship between the number of muscarinic cholinergic receptors, and the degree of the hyperreactive nasal symptoms in patients with hyperesthetic rhinitis, was investigated.

The results were as follows.

1. The number of muscarinic cholinergic receptors in the human nasal mucosa in patients with hyperesthetic rhinitis was significantly related $(\mathrm{p}<0.05)$ to the degree of hypersecretion induced by methacholine and to the frequency of nose blowing, based on observations in an allergy diary.

2. There was no relationship between the frequency of sneezing and the number of muscarinic cholinergic receptors.

Key words : muscarinic cholinergic receptors, hyperesthetic rhinitis, radioligand binding techniques

\section{緒 言}

自律神経受容体には副交感神経受容体である muscarinic cholinergic receptor (以下 mus 受容体), 交感神経 受容体の $\alpha$ adrenergic receptor (以下 $\alpha$ 受容体) および $\beta$ adrenergic receptor (以下 $\beta$ 受容体)がある. 鼻粘膜に 扣いて, mus 受容体は主として鼻腺分泌機能に関与し, $\alpha$ および $\beta$ 受容体は鼻粘膜血管運動に関与する.
鼻過敏症症例の鼻腺は正常者の鼻腺と比較して一定量 のアセチルコリンに対し過剩に反応する1)。これには鼻 腺の数, 量の増加とともに mus 受容体数の変動が要因 のひとつと考学られる．そこで今回著者は，ヒ卜鼻過敏 症症例に打ける臨床的な鼻過敏症状の程度と mus 受容 体数との相関性について検討を加えたので報告する。 


\section{研究対象および方法}

\section{1. 研究対象}

中等症以上で $11 \sim 41$ 歳 (平均 17 歳)の男性 10 例, 女性 5 例の鼻過敏症症例. 5ち, 通年性鼻アレルギー（主抗原 ハウスダスト)は12例, 血管運動性鼻炎は 3 例であった.

2. 検査スケジュール

図 1 に検査スケジュールを示す. 鼻粘膜所見, 鼻汁中 好酸球検査, 鼻粘膜誘発試験, 皮内テスト, RAST ス コア，RIST IgE 測定を施行した後，2 週間薬物投与を 中止し，アレルギー日記を用いてその間の鼻過敏症状の 程度を記録した. 2 週間後，塩化メサコリン $14 \mathrm{mg}$ $(0.36 \mathrm{ml})$ を投薬用入カニカルスプレー（西独・Peiffer 社製)を用いて鼻粘膜に投与し，10分間に誘発される鼻 汁量を測定した。鼻汁量は既報2)の吸引管法にて採取， 測定した。

\section{3. 鼻粘膜採取}

検査終了後も薬物療法は中止したまま，全身麻酔下に 下鼻甲介粘膜切除術を行い，鼻粘膜を採取した．前投薬 は用いず，麻酔導入薬にはチオペンタールナトリウムお よび塩化スキサメトニウムを，麻酔維持には笑気一酸素一 エンフルレン (GOE) を用いた。 また下鼻甲介粘膜切除 が終了するまでは，アトロピン，エピネフリン，局所麻 酔薬などの薬物は全く使用しないように留意した。

\section{4. 鼻粘膜粗膜標本作製法}

採取した鼻粘膜を氷冷下に剪刀を用い, 細切し, 氷冷 $50 \mathrm{mM}$ Tris/ $\mathrm{HCl}$ buffer, pH 7.4 (以下 buffer A) で洗浄 し，血液成分を除去した。これを10倍量の氷冷 buffer

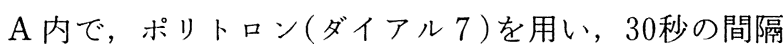
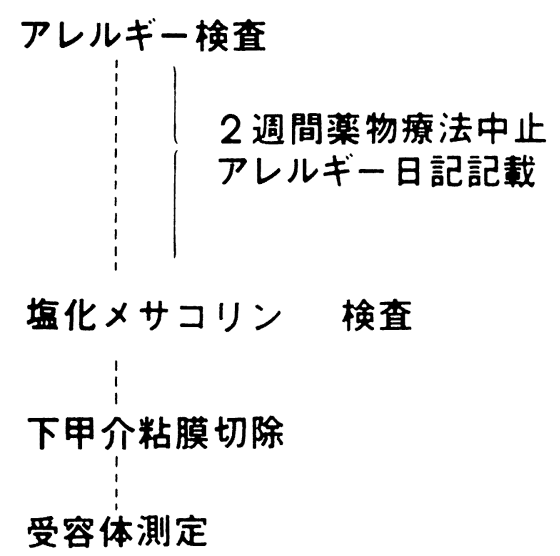

図1検査スケジュール
をおいて 2 回ホモゲナイズした後, $500 \mathrm{G}$ で10分間低遠 心し，その上清をナイロンメッシュで濾過した。慮液を $50,000 \mathrm{G}, 4^{\circ} \mathrm{C}$ で 10 分間超遠心分離し, 沈渣を水冷 buffer A に再浮遊させ, 同様の超遠心を計 3 回行った. 最終沈渣を incubation buffer (50 mM Tris/ $\mathrm{HCl}$ buffer, $\mathrm{NaCl} 120 \mathrm{mM}, \mathrm{KCl} 5 \mathrm{mM}, \mathrm{CaCl}_{2} 2 \mathrm{mM}, \mathrm{MgCl}_{2} 1 \mathrm{mM}$, $\mathrm{pH} 7.4) 6 \mathrm{ml}$ で再浮遊させた後, ポリトロン(ダイアル 5 )にて再度ホモゲナイズし， $-80^{\circ} \mathrm{C}$ で涷結保存した.

5 . 蛋白量測定

Bio-Rad Laboratories 社製 Bio-Rad protein assay kit にて施行した. assayは100〜 $500 \mu / \mathrm{ml}$ の蛋白濃度で行 った.

6 . receptor binding assay 法

Yamamura $5^{3)}$, Isibe $5^{4)}$ の方法に準じて行った.

Radioligand は, ${ }^{3} \mathrm{H}$-QNB (quinuclidinylbenzilate ; 30.2 $\mathrm{Ci} / \mathrm{mmol}$, New England Nuclear) を用いた。 また基礎 実験の結果からインキュベート温度・時間は $25^{\circ} \mathrm{C} て ゙ 60$ 分間行った. 受容体の最大結合数 (Bmax) 扣よび解離定 数 $(\mathrm{Kd})$ は, Scatchard 解析により求め, 回㷌曲線は最 小二乗法により作製した。この Bmax は蛋白 $1 \mathrm{mg}$ あた りの受容体数 (femtomol/mg protein)を, Kd は親和性 (nM) を示す。すべての実験は triplicate で行った.

7 . 推計学的検討

有意差検定には $\mathrm{t}$ 検定を用い， $\mathrm{p}<0.05$ を有意差あり とした．値は平均値士標準誤差で表現した。

\section{結果}

塩化メサコリン誘発鼻汁量と 1 日あたりの平均擤鼻回 数を比較すると,相関係数 0.80 と高い相関を示し(図 2 ), mus 受容体数と 1 日の平均擤鼻回数, および mus 受容 体数と塩化メサコリン誘発鼻汁量でも比較的高い相関が 認められた(図 3，4). しかし，mus 受容体数と1日の 平均くしゃみ回数(図 5 ), mus 受容体解離定数と 1 日 の平均擤鼻回数（図 6 ) とではいずれも有意な相関性を認 めなかった。

\section{考察}

鼻過敏症に拈ける症状の発現には, 種々の因子が関与 しているが，その1つとして自律神経系のアンバランス があげられる．鼻粘膜血管扣よび鼻腺はともに交感神経 ・副交感神経の二重支配を受けている，鼻粘膜血管におい ては交感神経優位であり，鼻腺では副交感神経優位であ 


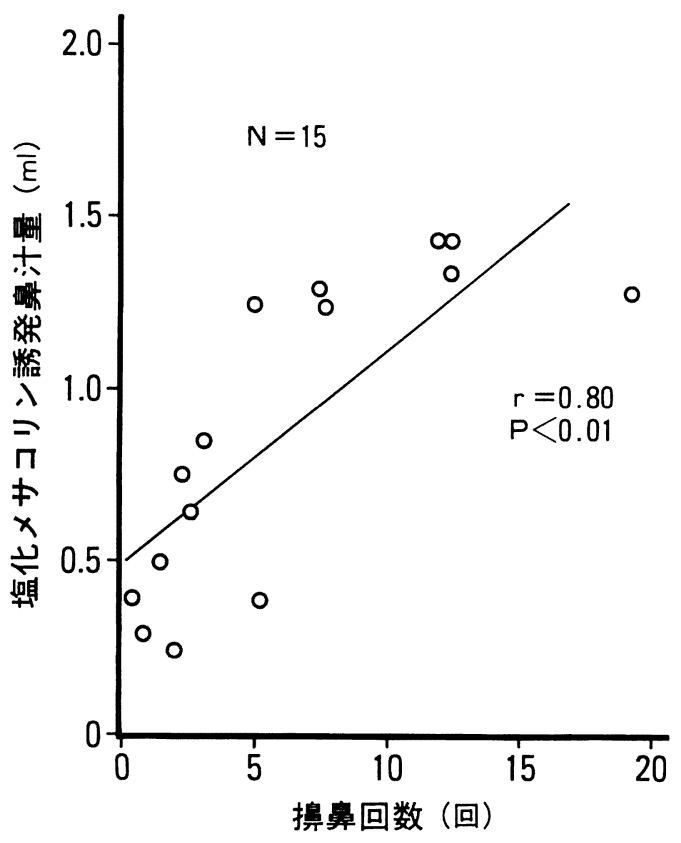

図 2 塩化メサコリン誘発鼻汁量と 1 日の平均擤鼻回数との相関

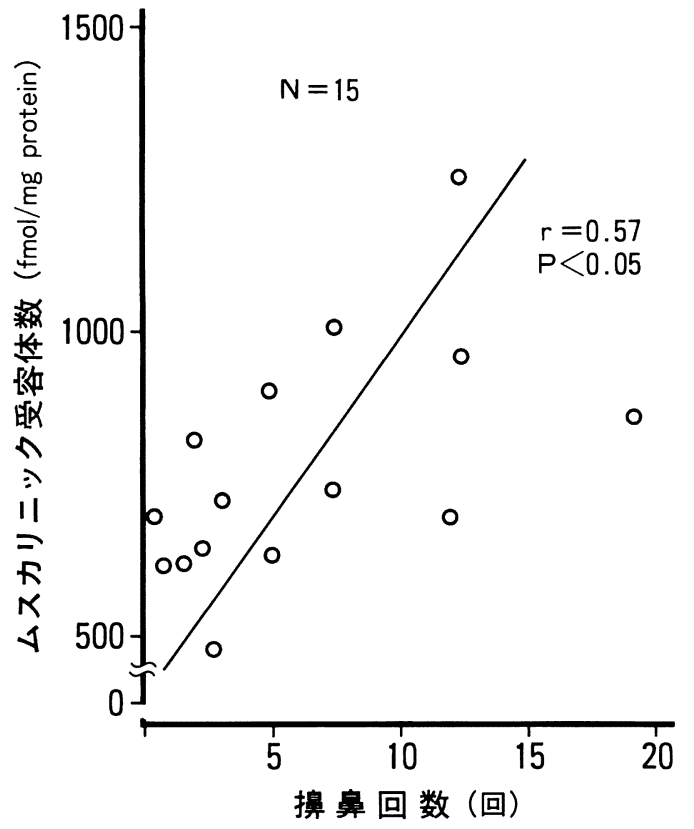

図 3 ムスカリニック受容体数と 1 日の平均擤鼻回数との相関

る. 組織学的にも副交感神経終末は主に鼻腺に, アドレ ナリン作働性線維は主として鼻粘膜血管周囲に存在す る5)6) receptor binding assay法を用い, ヒト鼻アレル

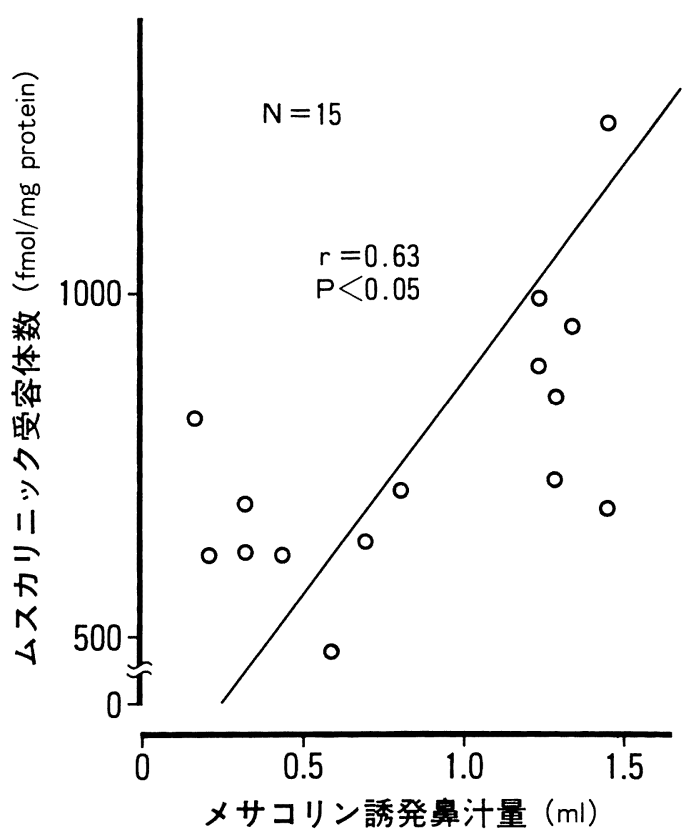

図4ムスカリニック受容体数と塩化メサコリン誘発鼻汁量と の相関

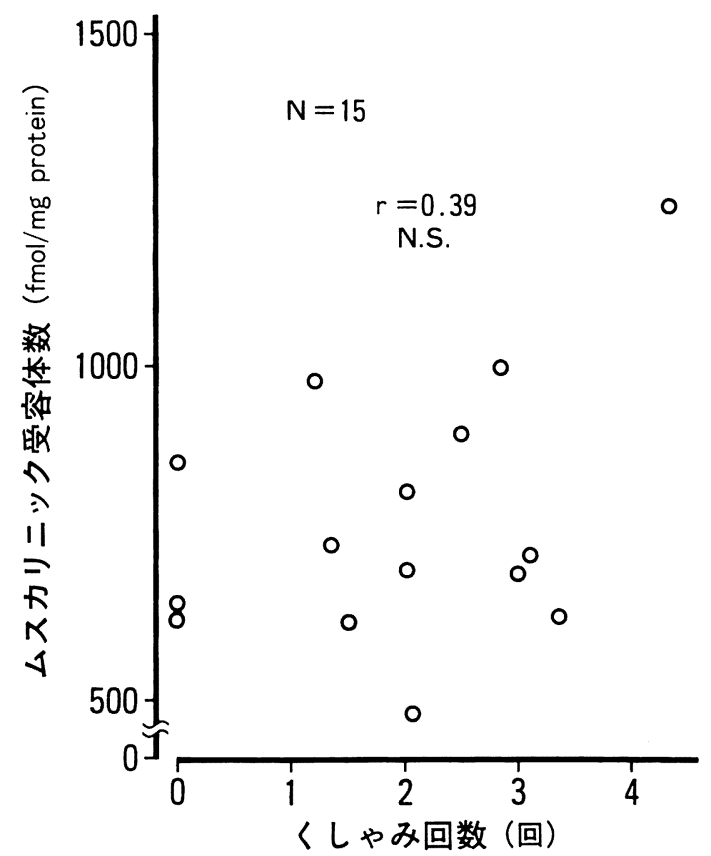

図 5 ムスカリニック受容体数と 1 日の平均くしゃみ回数との 相関

ギー症例の鼻粘膜における自律神経受容体数を測定する と, 慢性副鼻腔炎症例と比較して mus 受容体数の増加, 


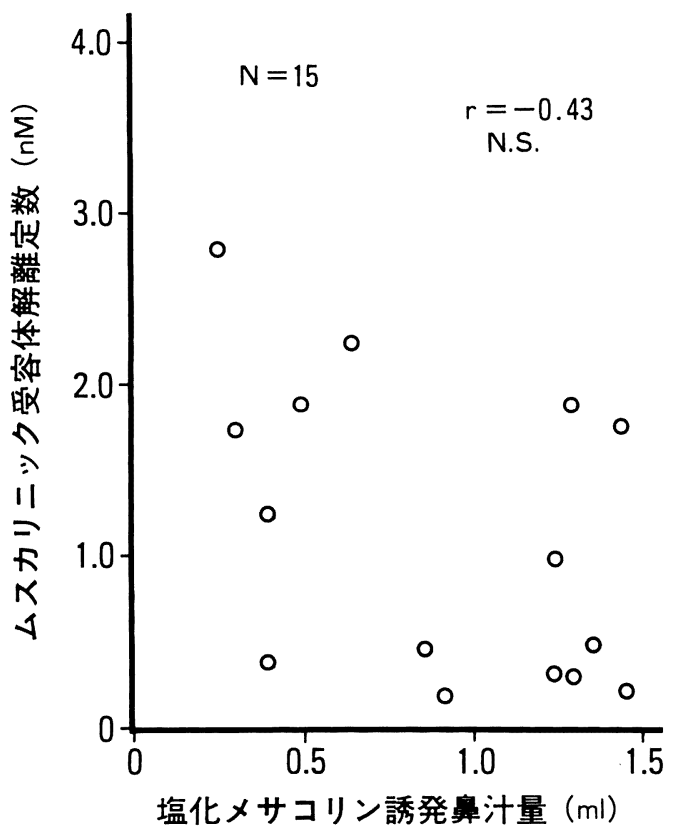

図 6 ムスカリニック受容体解離定数と塩化メサコリン誘発鼻 汁量との相関

$\alpha_{1}$ および $\beta$ 受容体数の減少が認められる47)，著者らは， すでに実験的鼻アレルギーモルモット鼻粘膜に拈いては, 感作だけでは mus 受容体数が増加せず，抗原誘発によ る鼻過敏症状の反復により初めて増加が認められること, 鼻アレルギー治療薬の投与により鼻アレルギー群の増加 した mus 受容体数が正常群の值に近づくことを報告し た8)。これは, 鼻過敏症状発現扣よびその程度と受容体 数の変動に相関性が存在することを示唆している.

ヒト鼻過敏症の臨床症状のうち鼻汁過分泌に㧊いては, ヴィディアン神経切断術による検討からケミカルメディ エーターの鼻腺に対する直接作用によるものは少なく, 神経反射を介する mus 受容体の関与によるものが大部 分であることが判明している229). 著者の実験結果につ いて検討してみると，まず塩化メサコリン誘発鼻汁と 1 日の擤鼻回数は (図 2 ) 相関係数 0.80 , 危険率 $1 \%$ 未満で 有意な相関性を示す.すなわち, 塩化メサコリン誘発に 対する鼻腺の反応はヒ上鼻過敏症症例に抢ける臨床的な 鼻汁過分泌状態をよく反映している. mus 受容体数と 塩化メサュリン誘発鼻汁との相関性をみると(図 4), 相 関係数 0.63 , 危険率 $5 \%$ 未満で有意な相関が認められる. さらに mus 受容体数と 1 日の擤鼻回数とでは相関係数 0.57 , 危険率 $5 \%$ 末満で有意な相関性が認められる(図 3).これに対し，mus 受容体解離定数と1日の擤鼻回 数に扣いては相関が認められない(図 6 )。鼻汁分泌機序 を考虑すれば，その発現に mus 受容体の関与が大きな 比重を占めることは容易に想像され，今回の実験によっ て, mus 受容体数と鼻汁過分泌の程度とがよく相関す ることが確認された。

自律神経受容体を介寸る鼻過敏症状の程度は, 自律神 経終末より放出される神経伝達物質の量と効果器に扣け る受容体数扣よび親和性の程度に左右される，鼻過敏症 における鼻汁過分泌発症機序は，その大部分が神経反射 を介したものであり，今回の実験結果から，mus 受容 体数のほうが受容体の親和性に比べ，より鼻過敏症状の 程度をよく反映していると考兄られる。

くしゃみ回数と mus 受容体数については, 相関性を 認めなかった(図 5 )。くしゃみ症状発現に沶いては, 知 覚入力は鼻粘膜を介寸るがそれに対応寸る出力は呼吸筋, 喉頭筋群に達する.すなわち, 効果器としての鼻粘膜自 律神経系の関与が希薄であることを反映していると考兄 られる99.

今回の実験結果から, 鼻汁過分泌の程度と mus 受容 体数の多寡とはよく相関することが証明されたが，この 受容体数の変動がぞのような機序で生ずるかはいまだ明 らかにされていない，われわれは，さきに実験的鼻アレ ルギーモルモット鼻粘膜に扔いては，感作だけでなく鼻 過敏症状が反復されることにより初めて mus 受容体数 が増加することを報告し, 受容体数の変動には抗原抗体 反応の結果放出されたケミカルメディエーターの関与が 考えられると結論つけたて7。比鼻アレルギ一症例にお いても鼻過敏症状の反復により鼻粘膜過敏性が元進する ことが知られて招り，これら受容体数の変動も二次的な ものである可能性が強いと考光られ，今後の検討課題で ある。

\section{結 論}

1. ヒト鼻過敏症症例の鼻粘膜における mus 受容体 数と鼻汁過分泌の程度とは上く相関する.

2.くしゃみと mus 受容体数には相関性がなく, 症 状の発現には主に知覚神経反射を介しており, 鼻粘膜自 律神経系の関与は少ない。

\section{参考文献}

1) Asakura K, Enomoto K, Ara H, et al : Responsiveness to 
methacholine stimulation in allergic rhinitis patients. Arch Otorhinolaryngol 239 : 273 278, 1984.

2 ) Konno A, Terada N and Okamoto $\mathrm{Y}$ : The role of chemical mediators and mucosal hyperreactivity in nasal hypersecretion in nasal allergy. J Allergy Clin Immunol $79: 620 \sim 627$, 1987.

3 ) Yamamura HI and Snyder SH : Muscarinic cholinergic binding in rat brain. Proc Natl Acad Sci U.S.A. 71 : 1725 1729, 1974

4) Isibe T, Yamasita T, Kumazawa T, et al : Adrenergic and cholinergic receptors in human nasal mucosa in case of nasal allergy. Arch Otorhinolaryngol 238 : 169 173, 1983.

5 ) 今野昭義, 寺田修久, 伊藤永子：鼻アレルギーと自律神経. アレルギー診療 $5:$ 133〜145, 1986.

6 ) Konno A, Terada N and Okamoto $\mathrm{Y}$ : Responses of resistance and capacitance vessels in human nasal mucosa to -receptor agonists. ORL $49: 206 \sim 213,1987$.

7 ) 寺田修久, 今野昭義, 岡本美孝, 他：ヒト鼻アレルギーお よび感作モルモットに打ける鼻粘膜自律神経受容体につい て. 日耳鼻 $88: 1153 \sim 1161,1985$.

8 ) 寺田修久, 今野昭義, 安藤英樹, 他 : 卵白アルブミン感作 モルモットに打ける鼻粘膜ムスカリニック受容体の変化と 薬物療法による影響. 日耳鼻 $91: 847 \sim 855,1988$.

9 ) 野中 聡, 太田善博：〈しゃみの神経機構と呼・吸気二 ューロン活動. 日耳鼻 $88: 760 \sim 770,1985$.

$$
\left(\begin{array}{l}
\text { 原稿受付: 平成 } 9 \text { 年 } 3 \text { 月 } 27 \text { 日 } \\
\text { 原稿採択 : 平成 } 9 \text { 年 } 5 \text { 月 } 7 \text { 日 } \\
\text { 別刷請求先 : 安藤英樹 } \\
\text { 干 } 011 \text { 秋田市土崎港中央 } 4-5-45 \\
\text { 秋田組合総合病院耳鼻咽喉科 }
\end{array}\right)
$$

